\title{
Children in Relation: Rethinking Early Childhood Education ${ }^{1}$
}

\section{Sally Lubeck}

The National Association for the Education of Young Children (NAEYC, 1986; Bredekamp, 1987) has published guidelines which define "developmentally appropriate" practice for all children birth through eight. These guidelines have now come under criticism, however, for a variety of reasons. Researchers have argued that they present a false impression of consensus (Walsh, 1991), that they are premised on a developmental theory characterized by ethnocentric bias (Bowman \& Stott, 1994), and that they represent cultural values that are not universally shared (Jipson, 1991; Wiliams, 1994; Phillips, 1994). This article holds likewise that the promulgation of guidelines based on universalist assumptions places racial, ethnic, and linguistic "minority" children and parents at a disadvantage and contributes to the very processes that early childhood educators seek to remedy. After reviewing an extensive research literature which shows children from traditionally disadvantaged groups in relation, the article concludes that the poor scholastic performance of disproportionate numbers of children should be attributed to interactional and relational factors rather than to innate capabilities or to parental "inadequacy."

In 1986 the National Association for the Education of Young Children (NAEYC) published a series of guidelines which detailed how young children aged four and five were to be reared in day care centers, preschools, and schools throughout the nation. The guidelines were later expanded and published in an edited volume which defined practice for children birth through eight. This monograph (Bredekamp, 1987) has come to be known within the field of early childhood education as "the guidelines for developmentally appropriate practice (DAP)" or, commonly, "the green bible." By 1992, over 300,000 copies had been sold. The guidelines essentially argue that all children develop in the same way and that a common child-rearing practice is therefore warranted: "The principles guiding developmentally appropriate programs are universally applicable" (Kostelnik, 1992, p. 22); "DAP is for all children" (Bredekamp \& Rosegrant, 1992, p. 5).

The position statement for developmentally appropriate programs (Brede-

Sally Lubeck, The University of Michigan. Address correspondence to School of Education, 610 East University, 4216B SEB, Ann Arbor, Michigan 48109-1259. 
kamp, 1987) states that all children will benefit from the same type of experiences, experiences that would be expected to vary only according to the age and "individuality" of children. Developmental appropriateness thus incorporates two central tenets: "There are universal, predictable sequences of growth and change that occur in children during the first 9 years of life," but "each child is a unique person with an individual pattern and timing of growth, as well as individual personality, learning style, and family background" (p. 2).

Certain conditions are held to facilitate development for all children:

- Children learn best through self-initiated, self-directed, and self-chosen activity. (p. 7)

- The teacher facilitates children's learning by providing a variety of activities and materials and by talking with children about their play. (pp. 3, 5, 7)

- Different types of activities and materials are appropriate for children of different ages. (pp. 3-5)

- Children learn through play. Transformational materials (sand, water, clay, blocks), puzzles, manipulatives, dramatic play props, science equipment, books, records, paper, paint and markers, and so on are all appropriate for early education classrooms. (p. 4)

- All children should be exposed to multicultural activities, materials, and equipment. (p. 7)

The guidelines are rendered official through four principal means. First, they are premised on the assumption that all children develop in the same way. Second, the guidelines are legitimizated by proclaiming that they represent the "consensus" view of the profession and widespread disperson of and agreement with the ideas set forth. Third, they claim legitimization through science: "Human development research indicates ..." (p. 2). Finally, they have been rendered official through the affirmation of "professional-client" relationships. Those who are informed about the type of practice advocated are presumed to be more knowledgeable about raising children. Therefore, teachers schooled in these principles are expected to advise family members on "child development knowledge, insights, and resources" (p. 12).

The guidelines appear to represent agreement among early childhood professionals on issues of curriculum, adult-child interaction, home-school relations, and the assessment of children's development and learning broadly defined. They have come under criticism, however, for a variety of reasons. Walsh (1991) argues that the guidelines present a false impression of consensus. Teachers express different views of development, and researchers have differences of opinion on such questions as whether stages are, in fact, universal, whether development is an individual process or a socially mediated one, and whether development precedes or follows learning. Jipson (1991) uses the classroom journals and personal narratives of 30 early childhood educators to 
show how the guidelines represent cultural values that are not universally shared. She illustrates how teachers themselves frequently see the contrast between professional and community notions of how children should be reared. For example, Alice, a Native American teacher, discusses how parents and tribal elders met with Head Start personnel to plan a program "that teaches the values, language, traditions, and practices of their tribal culture" (p. 133), while Ann, a Euro-American teacher, worries that some African-American children are not learning in her developmentally appropriate classroom. Finally, Kessler (1991a) registers concern that parents, teachers, and other community members who may have different ideas about what children need are summarily dismissed as uninformed.

What appears to be a debate between those who are well-informed by current research in child development and those who are not is, in reality, a debate between individuals who hold different values about the purposes of schooling, what counts as legitimate knowledge, and presumably the nature of the good life and the just society. (p. 193)

Elsewhere Kessler (1991b) makes the case that an alternative metaphor, "schooling for democracy," should replace "development" as the prime justification for an early education practice. In a review of this work, Lubeck (1991) notes that "reconceptualizers," in arguing for a less parochial approach to theory and method in the field, have moved away from the empirical-analytic science tradition and drawn more on interpretive and critical theory paradigms; in the process, attention has focused on the wider social milieu in which children's lives are embedded.

These writers essentially maintain that a universalist conception of practice neither reflects the diversity of views within the field nor takes into account differences in cultural beliefs and practices. The "universalist" view suggests that all American children would be better off if they were reared by teachers according to largely white, middle-class norms. What has been lacking to date is a way of thinking about such critiques that clarifies the implications of current practice and frames alternative conceptions.

Traditionally, early childhood education, like the field of education generally, has been dominated by the assumptions and methods of psychology (e.g., Bloch, 1987, 1991). In recent years psychologists have themselves questioned these assumptions, specifically, "spurious norms of development, the individuation of psychology, . . . the culture became, in effect, a constant, and [the use of] natural science methods and concepts" (Ingleby, 1986, p. 32). The burgeoning interest in a cultural psychology and in the writings of sociogenic theorists such as Vygotsky has signaled an increased awareness that development and learning occur in and are shaped by social context. Bronfenbrenner's work 
(e.g.,1979,1986) has likewise been vastly influential in prompting researchers to think about the ecology of human development. Nonetheless, context is too often depicted as a static field, and even Bronfenbrenner's model of microsystems, mesosystems, exosystems, and macrosystems seems curiously devoid of human activity.

The study of development and learning in context is gaining favor at a time when American schools are becoming ever more diverse. According to a 1991 Department of Education survey, fully 39 percent of children in public schools are from a "minority" group. ${ }^{2}$ It has been estimated that, by the year 2027, "minorities" will become the majority (Garcia, 1993). Nonetheless, disproportionate numbers of children, particularly those from African-American, Latino, Native American, and Hawaiian backgrounds, fare poorly in American schools. They are disproportionately represented in special education classes and differentially placed in low groups and tracks (e.g., Goodlad, 1981; Oakes, 1985, 1986), and they drop out of school at significantly higher rates than white students (National Center for Education Statistics, 1989). They are also more likely to be poor. Half of African-American children, and nearly 40 percent of Latino children live in families with incomes below the poverty line (Edelman, 1989).

In this paper I argue that the disjuncture between a "universalist" ideology and an increasingly diverse population creates the conditions for a reconsideration of the early education practice that has come to be widely promulgated. To this end, I examine research studies in the anthropology and sociology of education which are focused on social process. This work shows children from traditionally disadvantaged groups in relation: within their natal cultural group, with school personnel, and, broadly, within what John Ogbu (e.g., 1978) has called the American caste system. The first section explores the immediate interactive milieu of family and community and the "culture clash" children can experience in school; the second, the relational processes and structure of the school; and the third, the broad organization of society. This work also exemplifies what writers such as Outhwaite (1983) and Giddens (1984) have called a "system of relations."

The conclusion argues that notions of both social context and the individual have been inadequately theorized. Psychologists and early childhood educators have traditionally focused too narrowly on the individual, and despite the lip service given to social context, constructions of it have been largely abstract and static. A processual and relational view is important for understanding how children from certain groups within society are systematically disadvantaged. Class and race relations are reconstituted through actions and interactions of our own making. To the extent that the DAP guidelines celebrate as "universal" the child-rearing practices of the white middle class, they become part of the problem, not the solution. 


\section{CHILDREN IN RELATION}

In this section, three types of research studies are examined. A thorough discussion would require far more elaboration than space allows here. Instead the examples are meant to be illustrative rather than exhaustive.

\section{Relations between Home and School}

Anthropologists of education have examined continuities and discontinuities between the home and school experiences of children from ethnic, racial, and social class groups (e.g., Boggs, 1972; Florio \& Shultz, 1979; Philips, 1972, 1983; Ogbu, 1982) and the polarized socialization, or "clash of cultures," children can experience in schools (e.g., Heath, 1982; Labov, 1982; Schofield, 1982). Such work has provided descriptions of cultural misunderstanding and conflict in school and also in-depth descriptions of home and school contexts and how they differ.

Researchers working within this tradition have seen problems of poor school achievement to lie in the mismatch between the culture of the school and that of the children it serves. LeVine (1984) defines culture as "a shared organization of ideas that includes the intellectual, moral, and aesthetic standards prevalent in a community and the meaning of communicative actions" (p. 67). Since values, meanings, and behavior patterns differ for members of different groups, "mainstream" teachers and "minority" children can experience "culture clash."

Perhaps nowhere have the implications of being reared in a culture that differs from the one assumed in "mainstream" schooling been illustrated more graphically than in Shirley Brice Heath's classic educational ethnography, Ways with Words (1983). Based on nine years of fieldwork, Heath's book provides insight into the unconscious rules followed by members of two cultural groups in the United States. She describes in detail how children in these communities learn to use oral and written language and contrasts their cultural practices with those of the neighboring middle-class "townspeople." Trackton is an African-American community; Roadville a white working-class community. Both are located in the Piedmont Carolinas.

In Trackton, parents do not provide special toys or books for their children. Learning is more person- than object-oriented. Oral stories are creative and entertaining. Young boys are encouraged to perform verbal displays, while girls learn to "fuss." Young children of both sexes sit on the laps of older girls while they engage in jump-rope and hand-clapping play songs that are spontaneously constructed. Even when older children (infrequently) read to younger ones, they tend to select alphabet and nursery rhyme books that are read in a sing-song style with a distinct thythm.

Reading in Trackton tends to be a public social activity. Newspapers and 
letters are read aloud on the front porch, and they provoke jokes, stories, and debates about their meaning: "Reading alone, unless one is very old and religious, marks an individual who cannot make it socially" (p. 191). The reading that occurs is also action-oriented. Children learn to recognize letters, shapes, and colors, in order to decipher brand names on products. Reading is used to find out how to get somewhere or how something can be fixed. For Trackton parents, children "read to learn," not "learn to read" (p. 191).

The young children of Trackton see the written word as highly contextualized, and they approach reading holistically, recognizing labels on cereal boxes and reproducing the "look" of letters and newspapers. Heath concludes that

print for them was not isolated bits and pieces of lines and circles, but messages with varying internal structures, purposes, and uses. For most of these, oral communication surrounded the print. (p. 195)

These characteristics of print-in-use are present-and amplified-in communal church services. In prayers, hymns, and sermons, "there is a pattern of movement away from the form and formality of the written sources" (p. 203). In the raising of hymns, for example, a hymn begins as written until a member of the choir or congregation breaks in with new words or phrases. The congregation then repeats it and pauses until the next self-appointed leader brings forth another set. This active construction of meaning in a communal context of performance characterizes literate activity in the Trackton community. Words are something to be generated, shaped, and modified through interaction with others. As one preacher comments, "The words must live" (p. 233).

In Roadville, parents are more object-oriented, and they buy nursery furniture, clothing, toys, and books thought to be appropriate for infants, toddlers, and preschoolers. Books are shown to infants from about the time they are six months of age. Parents point out objects, name them, and ask children about them. Books and stories are considered literal and factual; preschoolers are expected to give "right" answers to questions about them. Oral stories are treated in much the same manner, as the storyteller drives to the point or moral or asks a child to see the relevance of the story to her or his own life. For community members, "Any fictionalized account of a real event is viewed as a lie; reality is better than fiction" (p. 187).

After age three, children are expected to listen to stories but not to interrupt them or to participate in their telling. Learning at home and at Sunday school is passive; children are expected to "listen and learn." Once children go to school, parents no longer read to them, nor do they provide them with the connect-thedots and sticker workbooks that were thought to prepare them for school.

Except with preschoolers, reading and writing are rare activities that tend to 
be done privately. Reading in Roadville is something people value, but few do. Residents subscribe to magazines and newspapers but seldom read them. Writing is done to remember, to communicate with teachers or distant relatives, to record accounts, to provide information, or to send greetings. Children learn to write "the right way," to stay within the lines, to write only what is "true," and to compose "thank-you" and other notes according to formulaic prescriptions. "In Roadville, the absoluteness of ways of talking about what is written fits church ways of talking about what is written" (p. 234). Heath concludes:

In Trackton, the written word is for negotiation and manipulation-both serious and playful. Changing and changeable, words are the tools performers use to create images of themselves and the world they see. For Roadville, the written word limits alternatives of expression; in Trackton, it opens alternatives. Neither community's ways with the written word prepare it for the school's ways. (p. 235)

Heath's descriptions demonstrate how cultural practices serve to orient children to the world. Once they enter formal schooling, however, their previous social experience and use of culturally acquired verbal and nonverbal conventions may differ from those held by the people who teach them. The result can be misunderstanding and miscommunication, which, in turn, can lead to children being labeled or placed in low-level learning groups. Heath argues that schools must lay the foundations for school-based literacy for children whose orientations to language and learning differ markedly from those assumed in schools.

Several educational reforms have been devised to minimize the interactional dissonance that some children experience when they enter school. The second half of Ways with Words chronicles many of the ways in which the teachers with whom Heath worked learned to "build bridges" so that children could "learn school." For example, preschool teachers, formerly upset with children who didn't behave as they expected, learned to revise and clarify implicit definitions of how time and space were to be used in their classrooms. They also learned to express requests directly while also providing opportunities for children to learn mainstream forms through story reading, the use of puppets, and other means.

An alternative response has developed under the rubric "culturally responsive education." Unlike the former example, which aimed to adapt the child to the school, the intent of this approach is, to the extent possible, to adapt the school to the child. This has been done by studying the learning strategies that are already familiar to children from particular groups and creating instructional formats that are continuous with their previous experience. Using this approach, the Kamehameha Early Education Project (KEEP) in Hawaii showed striking results in teaching Native Hawaiian children to read. Within a year, the children in the initial study, who were among the lowest in the country in 
reading achievement, began to perform at levels well above national norms (Calfee, Cazden, Duran, Griffin, Martus, \& Willis, 1981).

In the Kamehameha project, children were encouraged to set up the classroom themselves, because they were expected to be responsible for their living space at home. They frequently worked in peer groups, because Hawaiian children are accustomed to learning from a variety of people. They were taught through a comprehension approach (rather than phonics) that encouraged them to relate what they read to their own experience $(\mathrm{Au}, 1979)$, and they were allowed to use overlapping forms of speech while in reading groups, because Native Hawaiians conarrate and overlap speech with the speaker (Au \& Jordan, 1981).

More recently, early childhood professionals have recognized that children from some cultural groups may not prosper in the type of classroom promoted by the National Association for the Education of Young Children. DermanSparks (1992), for example, calls attention to the fact that the "EuropeanAmerican culture-centered classroom" is not appropriate for all young children and describes how strategies might differ in classrooms of ethnically diverse children, white European-American children, and children of color. Bowman (1992) likewise takes culture seriously and demonstrates how early education classrooms organized around dominant cultural practices can be out of sync with some children's acquired styles of learning and interacting.

A third emphasis has been to achieve a balance between home and school, through explicit efforts to help children to become bicultural (e.g., Laosa, 1984). In their case study of a bilingual program in which children were instructed in Spanish in one class and English in the other, Moll and Diaz (1987) study how a teacher's methods with students whose mother tongue is Spanish hamper their full participation in the classroom. Because of the children's limited English proficiency, the teacher assumed that their reading comprehension is limited and thus focused on decoding the text. The researchers were able to demonstrate that the students did understand and could give comprehensive, correct explanations in Spanish. The problem was not that their comprehension was poor, but that their expressive language in English was not yet developed to the point where they could respond easily to the teacher's questions. By encouraging the students to focus on comprehension and by allowing both students and researchers to use "bilingual communicative support" (p. 306) (i.e., switching to Spanish as necessary), the students, by the third lesson, were able to answer comprehension questions at grade level. By extension, Soto (1991) describes how children who are bilingual and bicultural can be supported in early education classrooms.

Through explicit efforts to teach children new cultural practices, to conform school practices to practices prevalent in the community, and to employ "bilingual communicative support" (Moll and Diaz, 1987, p. 306), practitioners in an 
increasing number of educational programs are striving to understand and acknowledge the familial and community contexts that are meaningful to children from certain ethnic, racial, and linguistic groups within American society.

\section{Relations within Schools}

Schooling in America is frequently perceived as an avenue of opportunity, yet ethnographers of schooling have shown it to be a site of social and cultural reproduction. Through complex processes of grouping, tracking, knowledge definition, and assessment, opportunity appears to be systematically denied to many children from disadvantaged backgrounds. As both Outhwaite (1983) and Giddens (1984) have written, such "structures" are not removed from human experience; rather, they are constituted and maintained through interactional processes. In this section, work drawing on three types of theory will be reviewed: theories of social reproduction, cultural reproduction, and cultural production.

\section{Social Reproduction Theory}

Social reproduction theorists such as Bowles and Gintis (1976) argue that social relations within schools are strongly determined by the division of labor in the sphere of economic production. As Stanley Aronowitz (in Willis, 1977) states:

The objective of public education [is] to produce workers at various levels of the capitalist labor process. Certain schools produce managers; others, technicians or professionals; the largest number generate industrial and clerical labor for the factories and offices of giant corporations. The curriculum, the authority relations, and the life in the classroom all conspire to persuade the working classes that, with few exceptions, their destiny [is] to remain on the bottom. (p. $\mathrm{x}$ )

The purpose of the school, in effect, is not to foster equality but to maintain inequality.

Social classes are believed to be reproduced in schools through differential funding (e.g., Kozol, 1991) and differential experience. Bowles and Gintis (1976) see a correspondence between the social relations of schooling and the social relations of work:

Predominantly working class schools tend to emphasize behavioral control and rulefollowing, while schools in well-to-do suburbs employ relatively open systems that favor greater student participation, less direct supervision, more student electives, and, in general, a value system stressing internalized standards of control. (p. 132) 
Anyon (1980) finds such differences in her study of classrooms for children of different classes. Working-class students were taught more by rote drill, while middle-class students were instructed in ways that encouraged discussion, analysis, and decision making.

Within schools, distinctions are also made which stratify children into groups and tracks according to their social class origins (e.g., Wilcox, 1982; Oakes, 1986; Connell, Ashenden, Kessler, and Dowsett, 1982). Thus, Rist (1970) finds students in a "ghetto" kindergarten to be placed in different reading groups according to their social class; these groups are then maintained in first and second grade. Rist argues that a teacher's expectation of success and failure creates a "self-fulfilling prophesy." Thus, schools would seem to socialize students for different roles and influence the development of attitudes which correspond to those roles.

Another study illustrates how, in the United States, these effects are strongly mediated by race and ethnicity. McDermott and Gospodinoff (1981) use videotapes of reading time in a first-grade classroom to show how students have different experiences in the classroom:

The top group consisted of white children, primarily Italian and Jewish. The bottom, or least literate, group consisted of three Puerto Ricans, one black and finally two white children, one of whom was considered the group's best reader and destined to move into a higher group, the other of whom was considered brain damaged. (p. 213)

In the top group all of the children are readers, and the transition from one to another goes smoothly. All are attentive, looking at their books, and in this postural configuration, they are not disturbed by other children. The bottom group, on the other hand, is more likely to look unfocused. Not all of the children in the bottom group can read, so the teacher must decide who will take the next turn. Students vie for the teacher's attention. In the interactional dissonance that ensues, the teacher observes what is happening elsewhere and may leave the group to intercede. Students also disturb the group at these times by asking for the teacher's assistance. Over the course of the year, the children in the bottom group spend one-third the amount of time reading as those in the top group, although they spend the same amount of time at the reading table. The net result is that "the children in the bottom group fall further behind the children in the top group for every day they spend in the classroom" (p. 228). The authors conclude:

If we wanted a mechanism for sorting each new generation of citizens into the advantaged and the disadvantaged, into the achieving and the underachieving, we could have done no better than to have invented the school system we have. (p. 229) 


\section{Cultural Reproduction Theory}

Cultural reproduction theories explain how dominant groups maintain their authority through ideology. What is presented as the cultural wealth and heritage of the entire society (e.g., art, music, and literature) is, in fact, knowledge and experience that is acquired by those who, because of their possession of real capital, are capable of appropriating it (e.g., Bourdieu, 1977; Bourdieu and Passeron, 1977).

Bourdieu provides an account of how power and privilege are transmitted through the educational system. He defines cultural capital as institutionalized knowledge and qualifications which serve to reproduce social class hierarchies. According to this argument, the illusion is created that the social and educational systems are meritocratic. In fact, however, grading and testing are based on the knowledge and skills which only the upper classes are likely to acquire. The construct is useful in understanding how schools and other dominant institutions define what counts as knowledge, set arbitrary standards, and serve particular interests.

Nonetheless, Bourdieu has been criticized for formulating a theory that is overly deterministic, merely reducing the cultural to the structural. Qualitative researchers such as Lareau and Willis have refined the theory in important ways by exploring the actual processes and practices which are thought to reproduce social relations through cultural means. In so doing, each has provided evidence supporting the theory and has also suggested how processes of reproduction might be interrupted.

Lareau $(1987,1989)$, for example, explores how privileged social standing provides advantages that enable an individual to comply with the standards set by schools. Through observations of first-grade classrooms in two schools, one in a professional middle-class community and the other in a working-class community, and through in-depth interviews with parents, teachers, and administrators, she provides an analysis of family-school relationships which illustrates how middle-class and working-class parents relate differently to schools, specifically to teachers' requests for parent participation. Resources, education capabilities, and characteristics of family life are shown to be forms of cultural capital.

Middle-class parents evidenced considerably higher rates of attendance at school events, but they also had more flexible work schedules and more resources at their disposal. They were more likely to have cars-and thus transportation to school events; they were also more likely to be able to afford a sitter and to procure other kinds of services (e.g., house cleaning, take-out food or meals in restaurants, tutors, lessons, and summer camp) that facilitated participation in school events or provided additional educational experiences for their children. In addition, middle-class parents were able and willing to help 
their children with school tasks; they related easily to teachers and intervened frequently on their children's behalf. Finally, where the working-class parents tended to live in extended-family groups and to spend a great deal of time with relatives, middle-class families formed close ties with other families that had children of the same age. Thus, the mothers were privy to a great deal more information about teachers in the school and other children in the class.

Lareau also explores another key concept (habitus) in the work of Bourdieu, the "disposition of individuals," that is shared by a group or class. These include shared attitudes, perceptions, and beliefs. She describes how teachers in both schools saw parental participation to be evidence of parents' interest in their children and their education. Although this seemed an accurate interpretation for the middle-class parents, who sought to share responsibility for their children's education, the working-class parents believed instead that it was their responsibility to provide economic and social support for their children, and that it was the teachers' responsibility to educate them. Lareau argues that the standards of the school have changed over time and that current standards and expectations serve to disadvantage working-class parents and children.

\section{Cultural Production Theory}

The study of cultural production arose, at least in part, in reaction to the mechanistic, deterministic vision of human behavior presented in reproduction theories. As the name implies, cultural production theory is concerned with how the disadvantaged actively oppose the forms of domination they experience.

Perhaps the most celebrated study from this vantage point is the Willis classic, Learning to Labor: How Working Class Kids Get Working Class Jobs (1977). The book is an ethnography of an English single-sex secondary modern school named Hammerstown Boys. Willis focuses on twelve working-class "lads" preliminary to their departure from school and six months after; he follows them, quite literally, onto the "shop floor." Through observation and participant observation, Willis comes to understand how the boys form an oppositional culture, or what he elsewhere refers to as "a creative collective selfmaking in the subordinate class" (Willis, 1981, p. 49).

Willis suggests that the "lads" achieve partial penetration; that is, they understand obliquely that qualifications have no real value; that upward mobility is, at best, unlikely; that the kind of work available to them is meaningless; and that, although individuals may "make it," the working class as a whole will not. The irony is that their very rebellion against a system stacked against them ultimately condemns them to relatively low-paid jobs with little opportunity for advancement. Willis's concept of "resistance" provides a counterpoint to theo- 
ries of social and cultural reproduction by demonstrating "how human agency accommodates, mediates, and resists the logic of capital and its dominating social practices" (Giroux, 1983, p. 282).

To mitigate the negative effects of schooling for members of vulnerable groups, those operating from these perspectives argue that power differentials in schools need to be addressed; that curriculum, assessment, and tracking practices need to be changed; and that disenfranchised groups must organize and contest the policies and practices promoted by dominant groups.

\section{Relations between Schools and Other Institutions}

Research described in this section explores the relationship between schooling and other dominant institutions and shows how the inequality some children experience in schools is endemic to the social order. Prejudice pervades not only schools, but American institutions generally.

Ogbu $(1978,1981,1987)$ has been the primary proponent of the theory that societies are organized into "castelike" systems (i.e., systems of social stratification based on group ascription) that privilege a dominant group and exclude and marginalize a minority group. He is critical of theories which blame parents and families for the inequities that minority group members experience, but he also derides theories which assume that children perform poorly in school because their cultural ways of interacting are different from those required in schools. He sees both to be "external" definitions of home and community influences which fail to understand behavior as "survival strategies" that enable oppressed peoples to cope with social and economic hardships (Ogbu, 1981, 1987).

In a widely cited study, Ogbu (1978) compared dominant and minority groups in three societies in which the groups were from the same "race" (India, Israel, and Japan) and dominant and minority groups in societies in which the races differed (Britian, New Zealand, and the United States). He found differences in school performance in all the societies, regardless of race. Ogbu's (1978) three-point alternative explanation calls attention to the complex means by which regressive race relations are maintained and perpetuated:

Schools translate the inferior social and technoeconomic status of blacks [and other castelike minorities] into inferior education; . . . caste barriers do not permit [them] to translate their academic skills into good jobs, income, and other benefits; and . . . both conditions result in attitudes and skills less favorable to the white middle-class type of school success. (p. 357)

Historically schools or classes for some groups (African Americans, Latinos, Native Americans) were segregated; today many exist in districts where the tax base is low, and classrooms are crowded, understaffed, and poorly equipped. Teachers of "minority" children frequently have low expectations for them, and 
many children come to be labeled as "problems." Members of castelike minorities have also experienced a "job ceiling"; that is, they have frequently been denied access to prestigious, well-paying jobs, even when they are qualified for them.

In response, members of these groups can develop "secondary cultural differences . . . as a response to a contact situation" (Ogbu, 1987, p. 322). These have been characterized as differences in cognitive style or as a type of cultural inversion in which the values, meanings, and behavior of one group (e.g., whites) are considered inappropriate for another group (e.g., blacks), and chosen values and behaviors are oppositional in nature: "Distrust of white people and skepticism make it harder for them to accept and follow school rules and standard practices that enhance academic success" (p. 334).

For Ogbu, the problem lies in society, and change is needed both in community values and in the "opportunity structure" of the school and of society more generally. In addition to school reforms, therefore, broad societal reforms are necessary and implicit in Ogbu's position: antidiscrimination policies and policies which redistribute income and increase the life chances of members of oppressed groups.

\section{SUMMARY AND CONCLUSIONS}

Beginning in the 1960 s, early childhood education was proposed as a way to ameliorate the poor scholastic performance of many children from traditionally disadvantaged groups. Great Society programs were premised on the assumption that education could transform society. Commenting on the developments that led to the establishment of Project Head Start, for example, Zigler and Muenchow (1992) write:

Prior to this period of "naive environmentalism," as the behaviorial psychologist Sandra Scarr later dubbed it, the prevailing view had been that biology was destiny. Since the basic nature of children's development was thought to be biologically set, there seemed to be little point in trying to alter it. But in the 1960s, when the pendulum swung from predeterminism to environmentalism, development came to be considered almost infinitely open to the manipulation of experts. The enthusiasm for improving intelligence was spurred by animal research, which seemed to indicate a link between early experience and later ability. . . . Many thinkers made a quick leap from sensory deprivation in animals to cultural deprivation as a cause of weak intellectual functioning among poor children. (p. 11)

The theory of cultural deprivation essentially attributes low levels of achievement to inadequate child-rearing practices (e.g., Bloom, Davis, \& Hess, 1965). Since environment was narrowly defined as what happened in the home, "experts" had two types of intervention at their disposal: (1) training poor mothers and other family members to interact with and stimulate their children in ways 
acceptable to members of the middle class (e.g., Gray and Klaus, 1965; Levenstein, 1972) and (2) developing preschool programs such as Head Start, in order to provide children with educational experiences they would not be likely to get at home. These assumptions have guided work with disadvantaged populations for nearly thirty years.

Although this ideology has become politically unacceptable, the assumptions which animate the guidelines for developmentally appropriate practice are strikingly similar to those which have traditionally guided early education initiatives:

1. The belief that some cultural practices are preferable (and others, if not "deficient," certainly less desirable).

2. The focus on individuals (children and family members) in an effort to rectify social ills.

3. The intent to provide children with experiences they are not likely to get at home.

4. The commitment to share with parents the knowledge that they ostensibly lack.

The ideology of cultural deprivation focuses on what is lacking; the DAP guidelines, on what should be present. Exemplifying what Foucault (1980) calls "normalizing" practices, emphasis is placed no longer on what is defective or wrong, but on what is defined as healthy and positive; at work is "productive" rather than "repressive" power.

In similar fashion, this paper has argued that the poor scholastic performance of disproportionate numbers of children from disenfranchised groups may be attributed more to interactional and relational factors than to innate capabilities or to parental "inadequacy." This explanation does not mean to trivialize the fact that the academic achievement of some children may be depressed for organic reasons, for example, because of damage suffered prenatally due to drug or alcohol exposure or poor nutrition. What it does challenge, however, is the notion that inordinate numbers of chldren are systematically disadvantaged because of the ways in which their parents and families have raised them.

The study of relations has become one of increasing import in the social sciences. The term has multiple referents: the connection of persons by origin, as in the term relative, and also the regularized relations of dominance and dependence that are reflected in expressions such as "race relations," "class relations," or "gender relations." Relation also connotes the notion of telling (to relate a story) and, indeed, the question of who "speaks" and who is silenced is of overriding concern to many contemporary postmodern and feminist scholars.

Historically, social theorists have offered a number of explanations for the seeming order of social life. Biological (e.g., Freud) and social (e.g., Marx) 
determinists saw individuals as powerless, seemingly buffeted by internal or external forces beyond their control. Phenomenologists, on the other hand, have focused on the intentional behavior of knowledgeable "actors." Thus, in social theory, the structural has been either preeminent or, for all intents and purposes, discounted. In seeing relations, or routinized social life, as the basic unit of analysis, the British theorist Anthony Giddens (1984) has instead worked the interface between structure and action, the social and the individual, the objective and the subjective.

Rather than offering a "grand theory" in the tradition of Marx or Parsons, Giddens has sought to address two fundamental questions: What explains the patterned nature of social practice? And how are social relations "stretched" across time and space? Paraphrasing Marx, Giddens (1984) argues that the stratified social order is both constituted and continuously reconstituted through human activity: "Men [let us immediately say human beings] make history, but not in circumstances of their own choosing" (p. xxi). Social structure, in this view, is not an entity removed from human experience. Rather, as Giddens writes:

The social systems in which structure is recursively implicated . . comprise the situated activities of human agents, reproduced across time and space. Analysing the structuration of social systems means studying the modes in which such systems, grounded in the knowledgeable activities of situated actors who draw upon rules and resources in the diversity of action contexts, are produced and reproduced in interaction. (p. 25)

In conjoining structure and action, Giddens recognizes the patterned and transsituational nature of social activity. For Giddens, structure thus has a distinctive meaning. Internal rather than external, it is what has been experienced: the "rules" which comprise the social order, the rules which, in their following, maintain it. Actors interpret the actions of others in the light of rules, which, in turn, structure action. Power-and the resources to effect change-is also a crucial concept in Giddens' theory. For actions to matter, those with authority must mold others to established norms. Thus, both "rules" and "resources" structure social practices. It follows that, if society is to change, the "rules" must be changed-as well as the power differences that maintain them. Yet it is too simple to say that the "decision" to maintain the status quo is conscious and intentional. Rather, a redundancy permeates the world of the powerful and the near-powerful, so that the ideational and material worlds are "in sync," and deviations from established norms appear not as options, but as aberrations.

Social practices-placing children in low-level reading groups in which little reading actually occurs, assuming a knowledge of things that children have as yet to be exposed, assessing children's achievement based on knowledge and formats that are unfamiliar, and, in general, assuming that they cannot $d o$ be- 
cause of who they are - are all relational practices that subordinate disproportionate numbers of children from particular social groups.

Since the 1960 s, policymakers and early education professionals have supported the notion that providing disadvantaged children with early education experiences would equalize opportunity. As Grubb and Lazerson (1982) point out, however, all of the compensatory programs that composed the War on Poverty - Head Start, Follow Through, Jop Corps, Title I-manifested, "a peculiar combination of humanitarian zeal and condemnation of the poor" (p. 48).

In the United States, modes of domination have become instantiated in seemingly innocuous (i.e., "meritocratic") practices which purport to differentiate individuals according to the "knowledge"-rather than the resources-they have acquired. In similar fashion, the DAP guidelines privilege a certain form of knowledge-and the professionals who hold that knowledge. In general, parents and professionals are not seen as partners in child rearing. Prescribing "best practice" instead has become the province of experts. The brief survey of work in the anthropology and sociology of education described above helps to place the idea of a single, normative practice in perspective. Indeed, it suggests that the promulgation of guidelines, based on universalist assumptions, may contribute to the very processes early childhood professionals seek to remedy.

Studies of social processes in context help to illuminate the relational practices that reproduce the social order, or in Giddens's (1984) terms, "The study of context, or of the contextualities of interaction, is inherent in the investigation of social reproduction" (p. 282). Interactions in reading groups, tracking practices across a school or schools, and the "caste" system that Ogbu describes are all manifestations of the relational practice that undergirds the social order and places children in jeopardy. This article has argued that the study of children in relation may encourage the development of policies and procedures that address more directly the routinized social practices that militate against their full participation in American society.

\section{NOTES}

1. An earlier version of this paper was presented at the annual meetings of the American Sociological Association, August 14, 1993, Miami, FL.

2. Terms such as nonwhite and minority have rightly been criticized because the usage identifies people as nonnormative and marginal. I use the term minority in quotes to underscore the fact that so-called minorities are becoming the majority in this country, and, indeed, represent the majority in the world today.

\section{REFERENCES}

Anyon, J. (1980). Social class and the hidden curriculum of work. Journal of Education 162: 6792.

Au, K. (1979). Using the experience-text-relationship method with minority children. The Reading Teacher 12: 677-679. 
Au, K., and Jordan, C. (1981). Teaching reading to Hawaiian children: Finding a culturally appropriate solution. In H. Trueba, G. Guthrie, and K. Au (Eds.), Culture and the Bilingual Classroom: Studies in Classroom Ethnography. Rowley, MA: Newbury House.

Bloch, M. (1987). Becoming scientific and professional: An historical perspective on the aims and effects of early education. In T. Popkewitz (Ed.), The Formation of School Subjects. Basingstoke, UK: Falmer Press.

Bloch, M. (1991). Critical science and the history of child development's influence on early education research. Early Education and Development 2(2): 95-108.

Bloom, B., Davis, A., and Hess, R. (1965). Compensatory Education for Cultural Deprivation. New York: Holt, Rinehart, \& Winston.

Boggs, S. (1972/1985). The meaning of questions and narratives to Hawaiian children. In C. Cazden, V. John, and D. Hymes (Eds.), Functions of Language in the Classroom. Prospect Heights, IL: Waveland Press.

Bourdieu, P. (1977). Cultural reproduction and social reproduction. In J. Karabel \& A. Halsey (Eds.), Power and Ideology in Education. New York: Oxford University Press.

Bourdieu, P., and Passeron, J. (1977). Reproduction in Education, Society, and Culture. Beverly Hills, CA: Sage.

Bowles, S., and Gintis, H. (1976). Schooling in Capitalist America: Educational Reform and the Contradictions of Economic Life. New York: Basic Books.

Bowman, B. (1992). Reaching potentials of minority children through developmentally and culturally appropriate programs. In S. Bredekamp and T. Rosegrant (Eds.), Reaching Potentials: Appropriate Curriculum and Assessment for Young Children. Washington, DC: National Association for the Education of Young Children.

Bowman, B. and Stott, F. (1994). Understanding development in a cultural context: The challenge for teachers. In B. Mallory and R. New (Eds.), Diversity and Developmentally Appropriate Practice(s): Challenge for Early Childhood Education. NY: Teachers College Press.

Bredekamp, S. (1987). Developmentally Appropriate Practice in Early Childhood Programs Serving Children from Birth through Age 8. Washington, DC: National Association for the Education of Young Children.

Bredekamp, S., and Rosegrant, T. (1992). Reaching Potentials: Appropriate Curriculum and Assessment for Young Children. Washington, DC: National Association for the Education of Young Children.

Bronfenbrenner, U. (1979). The Ecology of Human Development: Experiments by Nature and Design. Cambridge: Harvard University Press.

Bronfenbrenner, U. (1986). Ecology of the family as a context for human development research perspectives. Developmental Psychology 22: 723-742.

Calfee, R., Cazden, C., Duran, R., Griffin, M., Martus, M., and Willis, H. (1981). Designing Reading Instruction for Cultural Minorities: The Case of the Kamehameha Early Education Program. Report to the Ford Foundation, New York.

Connell, R., Ashenden, D., Kessler, S., and Dowsett, G. (1982). Making the Difference: Schools, Families and Social Division. Sydney: George Allen \& Unwin.

Derman-Sparks, L. (1992). Reaching potentials through antibias, multicultural curriculum. In S. Bredekamp and T. Rosegrant (Eds.), Reaching Potentials: Appropriate Curriculum and Assessment for Young Children. Washington, DC: National Association for the Education of Young Children.

Edelman, M. W. (1989). Children at risk. In F. Macchiarola and A. Gartner (Eds.), Caring for America's Children. New York: Academy of Political Science.

Florio, S., and Shulz, J. (1979). Social competence at home and at school. Theory into Practice 18: $234-243$.

Foucault, M. (1980). Power/Knowledge: Selected Interviews and Other Writings 1972-77. New York: Pantheon Books. 
Garcia, E. (1993). Talk presented in session "Preschool interventions for children at risk" at the meetings of the National Academy of Education, The University of Michigan, Ann Arbor, October.

Giddens, A. (1984). The Constitution of Society: Outline of a Theory of Structuration. Berkeley: University of California Press.

Giroux, H. (1983). Theories of reproduction and resistance in the new sociology of education. Harvard Educational Review 53: 261-293.

Goodlad, J. (1981). A Place Called School. New York: McGraw-Hill.

Gray, S., and Klaus, R. (1965). An experimental preschool program for culturally deprived children. Child Development 36(4): 887-898.

Grubb, N. \& Lazerson, M. (1982). Broken Promises: How Americans Fail Their children. Chicago: University of Chicago Press.

Heath, S. (1982). Questioning at home and at school: A comparative study. In G. Spindler (Ed.), Doing the Ethnography of Schooling. New York: Holt, Rinehart, \& Winston.

Heath, S. (1983). Ways with Words: Language, Life, and Work in Communities and Classrooms. Cambridge: Cambridge University Press.

Ingleby, D. (1986). Development in social context. In M. Richards \& P. Light (Eds.), Children of Social Worlds: Development in Social Context. Cambridge: Harvard University Press.

Jipson, J. (1991). Developmentally appropriate practice: Culture, curriculum, and connections. Early education and development 2(2): 120-136.

Kessler, S. (1991a). Alternative perspectives on early childhood education. Early Childhood Research Quarterly 6: 183-197.

Kessler, S. (1991b). Early childhood education as development: Critique of the metaphor. Early Education and Development 2(2): 137-152.

Kostelnik, M. (1992). Myths associated with developmentally appropriate practice. Young Children 47(4): 17-25.

Kozol, J. (1991). Savage Inequalities: Children in America's Schools. New York: Crown.

Labov, W. (1973). The logic of nonstandard English. In N. Keddie (Ed.), Tinker, tailor . . . The Myth of Cultural Deprivation. Harmondsworth, UK: Penguin.

Labov, W. (1982). Competing value systems in inner-city schools. In P. Gilmore and A. Glatthorn (Eds.), Children In and Out of School: Ethnography and Education. Washington, DC: Center for Applied Linguistics.

Laosa, L. (1984). Social policies toward children of diverse ethnic, racial, and language groups in the United States. In H. Stevenson and A. Siegel (Eds.), Child Development: Research and Social Policy. Chicago: University of Chicago Press.

Lareau, A. (1987). Social class differences in family-school relationships: The importance of cultural capital. Sociology of Education 60: 73-85.

Lareau, A. (1989). Home Advantage: Social Class and Parental Intervention in Elementary Education. London: Falmer Press.

Levenstein, P. (1972). Cognitive growth in preschoolers through verbal interaction with mothers. American Journal of Orthopsychiatry 40(3): 426-432.

LeVine, R. (1984). Properties of culture: An ethnographic view. In R. Schweder and R. LeVine (Eds.), Culture Theory: Essays on Mind, Self, and Emotion. Cambridge: Cambridge University Press.

Lubeck, S. (1991). Reconceptualizing early childhood education: A response. Early Education and Development 2(2): 168-174.

McDermott, R., and Gospodinoff, K. (1981). Social contexts for ethnic borders and school failure. In H. Trueba, G. Guthrie, and K. Au (Eds.), Culture and the Bilingual Classroom: Studies in Classroom Ethnography. Rowley, MA: Newbury House.

Moll, L., and Diaz, S (1987). Change as the goal of educational research. Anthropology and Education Quarterly 18(4): 300-311. 
National Association for the Education of Young Children. (1986). Position statement on developmentally appropriate practice in programs for 4- and 5-year-olds. Young Children 41(6): 20-29.

National Center for Education Statistics. (1989). Dropout Rates in the United States: 1988. Washington, DC: U.S. Department of Education.

Oakes, J. (1985). Keeping Track: How Schools Structure Inequality. New Haven: Yale University Press.

Oakes, J. (1986). Tracking, inequality and the rhetoric of school reform: Why schools don't change. Journal of Education 168: 61-80.

Ogbu, J. (1978). Minority Education and Caste. New York: Academic Press.

Ogbu, J. (1981). Schooling in the Ghetto: An Ecological Perspective on Community and Home Influences. Washington, DC: National Institute of Education. (ERIC \#ED252270).

Ogbu, J. (1982). Cultural discontinuities and schooling. Anthropology and Education Quarterly 13(4): 290-307.

Ogbu, J. (1987). Variability in minority school performance: A problem in search of an explanation. Anthropology and Education Quarterly 18: 312-334.

Outhwaite, W. (1983). Concept Formation in Social Science. London: Routledge \& Kegan Paul.

Philips, S. (1972). Participant structures and communicative competence: Warm Springs children in community and classroom. In C. Cazden, V. John, \& D. Hymes (Eds.), Functions of Language in the Classroom. Prospect Heights, IL: Waveland Press.

Philips, S. (1983). The Invisible Culture: Communication in Classroom and Community on the Warm Springs Indian Reservation. New York: Longman.

Phillips, C. (1994). The movement of African-American children through sociocultural contexts. In B. Mallory and R. New (Eds.) Diversity and Developmentally Appropriate Practice(s): Challenges for Early Childhood Education. NY: Teachers College Press.

Rist, R. (1970). Student social class and teacher expectation. Harvard Educational Review 40(3): 411-450.

Schofield, J. (1982). Black and White in School: Trust, Tension, or Tolerance? New York: Praeger.

Soto, L. (1991). Understanding bilingual/bicultural young children. Young Children 46(2): 30-36.

Walsh, D. (1991). Extending the discourse on developmental appropriateness: A developmental perspective. Early Education and Development 2(2): 109-119.

Wilcox, K. (1982). Differential socialization in the classroom: Implications for equal opportunity. In G. Spindler (Ed.), Doing the Ethnography of Schooling. New York: Holt, Rinehart \& Winston.

Williams, L. (1994). Developmentally appropriate practice and cultural values: A case in point. In B. Mallory and R. New (Eds.), Diversity and Developmentally Appropriate Practice(s): Challenge for Early Childhood Education. NY: Teachers College Press.

Willis, P. (1977). Learning to Labor: How Working Class Kids Get Working Class Jobs. New York: Columbia University Press.

Willis, P. (1981). Cultural production is different from cultural reproduction is different from social reproduction is different from reproduction. Interchange 12(2-3): 48-67.

Zigler, E., and Muenchow, S. (1992). Head Start: The Inside Story of America's Most Successful Educational Experiment. New York: Basic Books. 